\title{
A TÁNCOS TEST: EGÉSZSÉG, TESTI ELÉGEDETTSÉG, TESTHEZ VALÓ VISZONY, EVÉSI ATTITƯDÖK ÉS ÖNÉRTÉKELÉS VIZSGÁLATA TÁNCOSOK KÖRÉBEN
}

\author{
Szászi Beáta, egyetemi tanársegéd, Magyar Táncmúvészeti Egyetem, \\ Pedagógia és Pszichológia Tanszék, doktorjelölt, Debreceni Egyetem, \\ Humán Tudományi Doktori Iskola \\ Szabó Pál, CSc, egyetemi docens, Debreceni Egyetem, \\ Humán Tudományok Doktori Iskola, Pszichológiai Program
}

\begin{abstract}
Absztrakt
A szerzők célkitűzése az egészségi állapot, a testtel kapcsolatos elégedettség, az evészavarok tüneteinek, a testtel kapcsolatos befektetések és az önértékelés kérdőíves vizsgálata felnőtt táncosok körében.

Módszerek: Goldberg-féle Általános Egészségi Kérdőív, WHO Általános Jóllét Skála, Testtel Kapcsolatos Elégedettség Skálája, Emberalakrajzok Tesztje, Testtel Kapcsolatos Befektetések Skálája, Evési Attitűdök Tesztje és a Rosenberg Önértékelés Skála. Eredmények: A nôi táncosok $(n=71)$ 45,8\%-a, a férfiak $(n=35)$ 21,2\%-a rendelkezik jelentősebb tünetekkel vagy betegséggel. A nők 7,4\%-a $(\mathrm{n}=5)$ sovány, túlsúlyos a nők 5,9\%-a $(\mathrm{n}=4)$, a férfiak 15,6\%-a $(\mathrm{n}=5)$. A nők 11,6\%-ánál $(\mathrm{n}=8)$ fennáll az evészavarok kockázata. A modern társastáncosok a legelégedetlenebbek a testükkel, testsúlyukkal, náluk gyakoribbak az evészavar tünetek, míg a modern táncosok a legvédettebbek a testtel kapcsolatos szélsőségek terén. A 20 év alatti táncosnők szigorúbban ítélik meg és kevésbé védik a testüket, több bulimiás tünetük van, alacsonyabb az önértékelésük.

Következtetések: A táncoktatásban elméleti és gyakorlati tudást adó intervenciós program bevezetése szükséges, melyben az egészségügyi, oktatási és nevelési munkatársak is részt vesznek. Mindez elősegítheti a táncosok testi-lelki egészségének és állóképességének javulását, a pozitív testképet, a magasabb önértékelést és az evészavaros tünetek csökkenését.
\end{abstract}

Kulcsszavak: táncosok, testkép, testi elégedettség, evészavarok, önértékelés, egészségi állapot 
A táncos test

\section{BEVEZETÉS}

A tánc világa kettôs: számos lehetôségei mellett szélsőségei is a figyelem központjába kerültek. Az egyik legősibb múvészeti forma, a kommunikációnak, a személyiségfejlődésnek, az önkifejezésnek és a gondolatok átadásának sajátos entitása. A szakirodalom nagy része az emberi szervezetre, hangulatra, önértékelésre, testképre gyakorolt pozitív hatását emeli ki (Langdon \& Petracca, 2010; Allen, Telford, Telford \& Olive, 2019), emellett a táncterápiáknak a fizikai és lelki trauma feldolgozásában is kiemelt szerep jut (Pierce, 2014; Ventura, Barnes, Ross, Lanni, Sigvardt \& Disbrow, 2016). A másik oldalon ezzel szemben - leginkább a profi táncosok körében - magasabb prevalenciát mutat az evészavarok, testképzavarok jelensége, szorongás, depresszió, akut és krónikus kiégés, nők esetében menstruációs zavarok, gyakoriak a mozgásszervi sérülések (rándulások, ficamok, fáradásos törések) és a tartós, elégtelen kalóriabevitelhez kapcsolódó hiánybetegségek, anyagcserezavarok (Zuława \& Pilch, 2012).

De miért is alakulnak ki ezek a szélsőségek a táncosok körében? Testalkat és testsúly tekintetében a különböző táncmúfajok esetében eltérőek az elvárások, az azonban közös, hogy a cél a vékony, esztétikus test. A soványságért vívott harc gyakran felőrli a táncosokat, hiszen egyszerre kell vékonynak és erősnek lenniük. A megfelelés érdekében megjelenhetnek kóros evési szokások (koplalás, vízhajtás, extrém alacsony szénhidráttartalmú diéták) és az állóképességet, hangulatot érintő tünetek is. Utóbbi jelenségkört a balett-táncosok között vizsgálják leggyakrabban, azonban modern táncosok, utcai és jazz táncosok bevonásával végzett testtel kapcsolatos vizsgálatokról is olvashatunk (Krasnow \& Kabbani, 1999; Swami \& Tovée, 2009; Langdon \& Petracca, 2010; Diogo, de Oliveira Ribas \& Skare, 2016).

A táncosok számára meghatározott ideális test objektív számadatai kevéssé ismertek. A testalkati visszajelzésre általában a testsúly és testmagasság értékeiből számított testtömegindexet (angolul: body mass index, röviden: BMI) alkalmazzák. $\mathrm{Ez}$ az érték azonban a versenysportolók esetében - ide sorolva a táncképzésben résztvevôket is - nem minden esetben irányadó. Gyermekkorban nem használhatók a felnőttkori határértékek, mivel a testfelépítés még változik, a BMI érték mellé a gyermek nemének és korának megfelelő percentilis kategóriába sorolást kell elvégezni (Polyák, 2015). A testalkati követelmények és a vékonyság iránti szükséglet már a képzés elejétől kiemelt fontosságú. A teljesítménnyel kapcsolatos visszajelzés alapját a verseny képezi, így a hivatásos táncos pályára lépő gyermekek és kamaszok testhez való viszonya alapjaiban kapcsolódik össze a versengéssel, a megvonással, a folyamatos szinten tartással és az ehhez kapcsolódó szorongásokkal. Mindannyiunk közös célja, hogy ez megváltozzon, annak érdekében, hogy a táncosok egészségesen és ellenállóan kerüljenek az aktív pályára. Hogyan lehet a szélsôséges szomatikus és pszichológiai problémáktól megóvni a táncosokat és a képzésük során felkészíteni óket a folyamatos, kiélezett versenyhelyzetekre? Hol a határ a tánc pozitív és negatív hatásai között?

Jelen tanulmány célja, hogy tisztázza a testképpel kapcsolatos pszichológiai alapfogalmakat, és magyar mintán, a táncosok körében felmérje a testhez való viszonyt, a testméreteket, a testtel való elégedettséget, a fizikai és lelki egészséget, az életminőséget, az evési attitüdöket és az önértékelést. Az első hazai, átfogó vizsgálat 
eredményeit összegezzük, mely táncmúfaj és életkor szerinti bontásban hasonlítja össze a táncosok válaszait.

\section{TESTKÉP}

A testkép kifejezést az elmúlt két évtizedben a szaknyelvben és a köznyelvben is egyre gyakrabban használják, megjelölésére azonban más kifejezéseket is alkalmaznak (testvázlat, testséma, testértékelés, vizuális-poszturális testmodell, testhatár, testtudat), ami nehezíti a fogalom megértését. Gyakori tévedés, hogy a testtel kapcsolatos attitưdöket és a testtel kapcsolatos elégedettséget is a testkép szinonimájaként használják. Ezek a tényezők kapcsolatban állnak a testképpel, de éles határ van ezen fogalmak között. A testkép többdimenziós jelenség, a saját testhez kapcsolódó pszichológiai élményeket és attitűdöket, valamint ezek élmény szintû szerveződését foglalja magába (McCrea, Summerfield \& Rosen, 1982). Jelentős hatással van az énképre, a hangulatra, a közérzetre, a viselkedésre és az önértékelésre (Szabó, 2000).

Cash kognitív testkép modellje írja le jelenleg a legteljesebben a testképpel kapcsolatos tudásunkat (Cash, 2002). Eszerint a testkép a kulturális szocializáció (pl.: testtel kapcsolatos közösségi média-üzenetek), az interperszonális tapasztalatok (pl.: visszajelzések a szülő, tanár, edző, kortárscsoport részéről), a fizikai jellemzők (pl.: testsúly) és a személyiségi jellemzők (pl.: perfekcionizmus) összefüggő rendszerében alakul ki. A testképet kialakító és befolyásoló tényezők között cirkuláris okság feltételezhető, ugyanis nehéz eldönteni, hogy ezek a tényezők mikor jelentek meg, milyen hangsúllyal, és hogyan befolyásolják az egyéb faktorok jelenlétét vagy kialakulását. Ezek a befolyásoló tényezők hatással vannak a testkép-sémákra és a testtel kapcsolatos attitúdökre. Ide tartoznak a külső megjelenés sematikus feldolgozása, a testről megfogalmazott belső gondolatok, magyarázatok, következtetések, a testtel kapcsolatos érzések és végül az testtel kapcsolatos viselkedések is (pl.: korrigáló, önszabályozó viselkedések).

A testkép kialakulása összetett folyamat, az éntudat („én létezem, más vagyok, mint a külvilág tárgyai és emberei") megjelenésétől kezdődően a Cash által felvázolt modellig. Kisgyermekkorban a saját test mentális reprezentációként jelenik meg, létrejön a testséma, melyhez a késóbbiekben érzések és gondolatok kötődnek, ezt pedig interperszonális és intrapszichés tapasztalatok alakítják (Kearney-Cooke, 2002). Utóbbiak szoros kapcsolatban állnak a testtel kapcsolatos elégedettséggel, hiszen nagymértékben befolyásolják azt pozitív vagy negatív irányban. Az így kialakuló pozitív vagy negatív testkép meghatározásában nincs teljes körû egyetértés, Cash (2002) szerint a teljes testtel kapcsolatos elégedettségről és bizonyos testi adottságokkal kapcsolatos elégedettségről is írnak. Táncosok vizsgálata esetén valószínû, hogy a test egészével és részleteivel kapcsolatos elégedettséget is szükséges mérni.

A testtel kapcsolatos elégedetlenség gyermekkortól kezdve kockázatot jelent, súlya pedig tovább nő serdülőkorban, szélsőséges esetben testképzavarok, evészavarok és depresszió jöhet lére (Smolak, 2011). A médiaplatformok ezt az online térben tovább erôsítik, melynek hatására a serdülők internalizálják a diszfunkcionális gondolatokat, így a külső megjelenés és az erről szóló visszajelzések az önértékelés markáns részévé válnak. 


\section{A táncos test}

A testkép különösen fontos, hiszen a fejlődés során a személyiség és az identitás alapját képzi, a növekedéssel járó testi változások pedig minden fejlődési szakaszban hatnak a testkép komponenseire (Csenki, 2015). A testkép fogalma alapvetően kapcsolódik össze az önértékeléssel, az én-hatékonysággal és a teljesítménnyel, emellett a testtel való elégedetlenség az evészavarok kialakulásában is kiemelt szereppel bír (Lantos, Iván \& Pászty, 2008).

\section{TESTTEL KAPCSOLATOS SZÉLSŐSÉGEK A TÁNC VILÁGÁBAN}

Képzeljünk el egy kisiskolást, akinek az az álma, hogy táncmúvész legyen. Az iskolai teendők mellett minden kapacitását lefoglalja, hogy a szakmai órákon jó teljesítményt nyújtson, megfeleljen a testalkati követelményeknek, erős és hajlékony legyen, akinek kisugárzása is van. A növendékek közti verseny kiélezett, az elvárás magas. A teljesítmény javítása érdekében a társas és online térből érkeznek a jó tanácsok, fél információk: drasztikus edzéstechnikák, divatdiéták, súlycsökkentő trükkök, melyek ugyan rövid távon sikert hozhatnak, a diákok fizikai és/vagy lelkiállapota az idő múlásával egyre rosszabb lesz, hiszen a szélsőségek általában negatív következményekkel járnak.

\subsection{Sérülések}

A színpadi megjelenésre alkalmas, esztétikus test elérése érdekében a táncosok mindennapi célja az ideális testsúly beállítása és fenntartása. A tánchoz egyszerre szükséges állóképesség, izomerő, hajlékonyság és megfelelő ízületi stabilitás. A mozdulatsorok komplexek, a mozgástartomány gyakran igen széles. Eközben a mobilitás, a statikus és dinamikus erőkifejtés, a stabilitás és egyensúly egyaránt fontos. Újabb táncstílusok a testmozgás dinamizmusát kívánják meg: a mozdulatoknak élesnek és gyorsnak kell lenniük, a test pozícióját gyorsan és pontosan kell változtatni.

Mindez a táncosoktól stabil neuromotoros kontrollt, erőt, gyorsaságot, koordinációt, rugalmasságot és egyensúlyt kíván meg (Diogo et al., 2016).

A test igénybevétele amatőr és profi szinten is fájdalommal jár a táncosok körében. Egy brazil vizsgálat szerint a megkérdezett táncosok 58,6\%-a számol be fájdalomról, múfajtól függetlenül. A leggyakrabban jelentkezô sérülések a gerinc alsó szakaszán, a hát középső részén, a nyakcsigolyák és az alsó végtag területén jelentkeznek (Diogo et al., 2016). A sérülések táncosok körében leggyakrabban 8 és 16 éves kor között jelentkeznek, melynek oka a rossz testtartás, anatómiai anomáliák, rossz tánctechnikák, kevés bemelegítés és az izomcsoportok terhelésének az aránytalansága (Arabia, Arabia \& Hoyos, 2013). Azonban nemcsak a test szélsőséges igénybevétele áll a sérülések hátterében. Az elégtelen táplálkozás, a rosszul megválasztott diéták miatt csökkent csontsû́rûség is hozzájárul a fáradásos törésekhez.

\subsection{Testképzavar}

Számos vizsgálati eredmény alapján a mozgás segít csökkenteni a feszültséget, a szorongást, a depressziót, javítja a pszichológiai jólétet, az önértékelést, a testképet, tekintet nélkül a korra és a nemre. A fizikailag aktívabb embereknek sokkal pozití- 
vabb az énképük (Hausenblas \& Fallon, 2006; Nordin-Bates, Walker, Baker, Garner, Hardy, Irvine, Jola, Laws \& Blevins, 2012). A tánc emellett a testképre és a test megítélésére is jótékony hatással van (Burgess, Grogan \& Burwitz, 2006; Vaquero-Cristobal, Alacid, Muyor, \& Lopez-Minarro, 2013; Varnes, Stellefson, Janelle, Dorman, Dodd \& Miller, 2013). Ez már kisiskoláskortól mérhetô, Monteiro, Novaes, Santos és Fernandes (2014) megerősíti, hogy azok a 9-15 éves lányok, akik táncra járnak, magasabb önértékeléssel rendelkeznek, elégedettebbek a testtömegükkel és a külsejükkel. A szakirodalmi források áttekintése során azonban egymásnak ellentmondó eredményeket is találhatunk, mivel nem tudjuk pontosan, hogy a vizsgált csoportok milyen intenzitással és milyen múfajban táncoltak. A tánc hosszú távú hatását Ackard, Henderson és Wonderlich (2004) érdekes vizsgálatban mérte fel. Megállapították, hogy a gyermekkori táncórák valószínúleg hatással vannak a felnőttkori evési magatartásra, ami több, külsővel kapcsolatos múködésmódot és szabályozást is érint. Azok az egyetemisták ugyanis, akik gyermekkorukban táncra jártak, alacsonyabb ideális testtömeget jelöltek, alacsonyabb volt az impulzus-kontrolljuk és magasabb a karcsúság iránti vágyuk, ellentétben azokkal a hallgatókkal, akik nem látogattak táncórákat gyermekkorukban. A közlemény nem tér ki a gyermekkorban gyakorolt tánc múfajára.

A profi képzésben részt vevő táncosoknál minden korcsoportban általános a testtel kapcsolatos elégedetlenség (Kazarez, Vaquero-Cristóbal \& Esparza-Ros, 2018). Özgen és Kisac (2009) eredményei szerint az általuk megkérdezett táncosok 31,9\%-a elégedetlen a testével. Ez az elégedetlenség negatív testképet alakít ki, amit szélsőséges esetben testképzavar válthat fel. A testképzavar a komplex testélmény összetett zavara (Túry \& Szabó, 2000), jellemző tünete, hogy az egyén a saját testét nem tudja a realitásoknak megfelelóen meghatározni, hanem attól eltérő méreteket gondol, észlel a magáénak. A táncosok körében gyakoribb a testképzavar megjelenése (Ravaldi, Vannacci, Zucchi, Mannucci, Cabras, Boldrini \& Ricca, 2013), melyet az is alátámaszt, hogy általában megfelelő BMI mellett is fogyni szeretnének.

Táncos serdülők (12-17 évesek) körében magas a testtel kapcsolatos elégedetlenség mértéke, és ez különösen 14-16 éves korban mutat intenzív emelkedést. A testtel kapcsolatos elégedetlenség és a soványság iránti vágy erős, szignifikáns kapcsolatban állnak egymással, mely folyamathoz társulhat a rendezetlen evés is (Jones, Buckner \& Miller, 2014). Ezt az összefüggést felnőtt táncosok körében is megfigyelték, ahol a táncos csoport testtel kapcsolatos elégedetlensége és a soványság iránti vágya magasabb volt a nem táncos csoporthoz viszonyítva. A táncosok gyakran az előírtnál többet gyakoroltak, edzettek annak érdekében, hogy kalóriát égessenek, energiakészletük viszont alacsonyabb volt a kontrollcsoporténál (Robbeson, Kruger \& Wright, 2013). A túlzott gyakorlatokra vonatkozóan egy másik tanulmányban a táncosnők testedzésfüggőségét vizsgálták, női futókkal és jégkorongjátékosokkal összehasonlítva. Az eredmények azt mutatták, hogy a táncosok érték el a legmagasabb pontszámokat a testedzésfüggőség skálán (Pierce, Daleng \& McGowan, 1993).

A hasonló mértékû fizikai megterhelés és az átfedő problémák miatt gyakran vonnak párhuzamot a tánc és a sport között. Egy jellegzetes probléma, az ún. nói atléta triász mind a táncosoknál, mind a sportolóknál gyakori. A triász három öszszetevője a szükségesnél alacsonyabb kalóriabevitel (és az ebből fakadó soványság), a menstruáció zavara és az alacsony csontsûrúség (Tosi, Maslyanskaya, Dodson \& 


\section{A táncos test}

Coupey, 2019). 712 személy vizsgálata alapján a táncosok (n=199) kockázata nagyobb a triász kialakulására, mint a múkorcsolyázóké $(n=430)$ vagy a futóké $(n=83)$, a táncosok 72\%-a veszélyeztetett ebből a szempontból (Tosi et al., 2019). 18-35 éves profi balettos nők 40\%-ánál megállapították a női atléta triászt (Doyle-Lucas, Akers \& Davy, 2010).

\subsection{Evészavarok}

Az evészavarok kialakulásában és fennmaradásában számos biológiai, pszichológiai és szociokulturális tényező játszik szerepet. A két legismertebb evészavar, az anorexia nervosa és a bulimia nervosa mellett az elmúlt 30 évben újabbakat is leírtak: egészségesétel-függóség (orthorexia nervosa), falászavar (binge eating disorder), purgáló zavar (purging disorder) (Túry \& Pászthy, 2008). Terjedelmi korlátok miatt jelen tanulmányban csak az anorexia nervosa és a bulimia nervosa jellemzőit tárgyaljuk. E két súlyos pszichiátriai zavar tüneteit a DSM-5 kritériumrendszer pontosan meghatározza (American Psychiatric Association, 2013; 1. és 2. táblázat). Az evészavarok gyakori betegségek: nőknél az anorexia nervosa élettartam-prevalenciája 0,9\%, a bulimia nervosáé 1,5\%, a falászavaré 3,5\%, a szubklinikai evészavaroké pedig 10\% (Treasure, 2020).

A. Az energia bevitel a szükséges energiamennyiséghez viszonyított korlátozása, mely az életkor, nem, fejlődés és testi egészség szempontjából jelentősen alacsony testsúlyt eredményez. A jelentôsen alacsony testsúly definíció szerint olyan testsúly, ami alacsonyabb annál, ami minimálisan normális, vagy gyermekek és kamaszok esetében kevesebb, mint ami minimálisan elvárható.

B. Intenzív félelem a testsúlygyarapodástól vagy az elhízástól, vagy a testsúlygyarapodást akadályozó tartósan fennálló viselkedés a jelentôsen alacsony testsúly ellenére.

C. A testsúly vagy a testalak megélésének zavara, a testsúly vagy a testalak önértékelésre gyakorolt indokolatlan és aránytalan befolyása vagy a jelen alacsony testsúly súlyosságával kapcsolatos felismerés tartós hiánya.

Restriktív típus: Az elmúlt 3 hónap során a személynél nem jelentkezett visszatérô falásroham-epizód vagy öntisztító viselkedés (vagyis önhánytatás vagy hashajtó, diuretikum vagy beöntés abúzusa). Ebbe az altípusba azok a klinikai képek tartoznak, melyek esetében a testsúlyvesztést a személy elsősorban diétázással, koplalással és/vagy túlzott testmozgással éri el.

Falás/tisztulás típus: Az elmúlt 3 hónap során a személynél visszatérô falásroham-epizódok vagy öntisztító viselkedések (vagyis önhánytatás vagy hashajtó, diuretikum vagy beöntés abúzusa) jelentkeztek.

1. táblázat: Az anorexia nervosa kritériumai a DSM-5

(American Psychiatric Association, 2013) szerint 
A. Visszatérő falási epizódok. Egy falási epizódra az alábbiak közül mindkettő jellemző:

(1) Olyan mennyiségû étel fogyasztása jól körülírható időszak alatt (pl. egy adott kétórás időszakban), ami egyértelmúen nagyobb annál, mint amennyit a legtöbben hasonló idő alatt hasonló körülmények között elfogyasztanának.

(2) Az étkezés feletti kontroll hiányának érzése az epizód során (pl. olyan érzés, hogy a személy nem tudja abbahagyni az evést vagy kontrollálni, hogy mit és mennyit eszik).

B. Visszatérô helytelen kompenzátoros viselkedések a testsúlygyarapodás megakadályozására, például önhánytatás, hashajtók, diuretikumok (vízhajtók) vagy más gyógyszerek alkalmazása, koplalás vagy túlzott testmozgás.

C. A falás és a helytelen kompenzátoros viselkedések egyaránt átlagban hetente legalább egyszer jelentkeznek három hónapon át.

D. Az önértékelést a testalak és a testsúly indokolatlan és túlzott mértékben befolyásolja.

E. A zavar nem kizárólag anorexia nervosa során jelentkezik.

2. táblázat: A bulimia nervosa kritériumai a DSM-5

(American Psychiatric Association, 2013) szerint

A táncosok - speciális sportoló csoportokkal együtt - fokozott kockázattal rendelkeznek az evészavarok szempontjából. Számos vizsgálati eredmény utal erre, pl. egy metaanalízis szerint profi táncosoknál az evészavarok élettartam-prevalenciája $50 \%$, fiatal táncosoknál a pontprevalencia pedig 13,6-26,5\% (Hincapié \& Cassidy, 2010). Egy másik vizsgálatban 127 táncos lány közül csak 42,5\%-nak volt normális a testtömegindexe, 15,7\%-uk súlyos mértékben sovány volt (Burckhardt, Wynn, Krieg, Bagutti \& Faouzi, 2011).

Több adat áll rendelkezésre a felnőtt balett-táncosok evészavaraira vonatkozóan. Egy korai tanulmányban le Grange, Tibbs és Noakes (1994) fiatal felnőtt balerinák körében ( $n=49)$ vizsgálta az evészavarok prevalenciáját, a táncosnők (kor: 18,9 $\pm 1,9$ év) 4,1\%-ánál anorexia nervosát, 8,2\%-ánál részleges anorexiát mutattak ki. Felnőtt, profi balett-táncosok ( $\mathrm{n}=14$, életkor: 18-35 év) napi kalória bevitele a kontrollcsoport 76\%-a volt, és a nyugalmi metabolikus rátájuk is szignifikáns mértékben alacsonyabb volt, mint a kontrollcsoporté (Doyle-Lucas, Akers \& Davy, 2010).

Nascimento, Luna és Fontenelle (2012) profi női balett-táncosok körében ( $\mathrm{n}=19$, kor: 34,5 \pm 8,8 év) vizsgálta az evészavarok és a testképzavar megjelenését. Eredményeik szerint a balerinák 15,8\%-a anorexia nervosában, 10,5\%-a pedig egy speciális testképzavarban, a testdiszmorfiás zavarban szenvedett. A szerzők szerint a magasabb szépséggel kapcsolatos elvárások, a test nyilvános kitettsége és a próbatermekben a tükörrel való állandó szembesülés hozzájárulhat a balett táncosok körében a testképzavarok kialakulásához.

Serdülők körében az evészavarok gyakorisága hasonló, Liu, Tseng, Chang, Fang és Lee (2016) 442 középiskolás táncos növendéket vizsgált. Közöttük 15,4\% (68 fő) evészavarban szenvedett, az evészavaros csoport 47,1\%-ánál hangulatzavar, 


\section{A táncos test}

40,9\%-ánál pedig szorongásos zavar is jelentkezett. A kutatás szerint az evészavar kialakulásához leginkább a testsúllyal kapcsolatos ugratások csúfolódás, viccelődések és a testképzavar vezetett. Egy hasonló vizsgálatban,13-18 éves balett-táncos lányok csoportjában (n=239) 29,3\% beszámolt arról, hogy már koplalt, 9,6\% meghánytatta magát, 4,2\% pedig hashajtót szedett a testsúly kontrollálása céljából (Thomas, Keel \& Heatherton, 2011). Fontos rávilágítani, hogy a táncosokra vonatkozó vizsgálatokat áttekintve, a klinikai és szubklinikai evészavarok tünetei, illetve a depressziós és a szorongásos tünetegyüttes is megjelennek a vizsgálatok többségében.

Több múfaj profi és amatőr táncosait vizsgálta Diogo munkatársaival (2016), akik 13 év feletti klasszikus balettosokat, jazz táncosokat és utcai táncosokat vontak be vizsgálatukba. A táncosok 34,6\%-ánál fennáll az evészavar kockázata, ami leginkább a lányok, a balett-táncosok és a magas szorongás pontszámmal rendelkezők körében gyakori. Az evészavarok kevésbé gyakoriak a jazz táncosok körében. A minta majdnem 20\%-ánál fennáll a bulimia kockázata, amely a profi és amatôr táncosokat egyaránt érintette. Az amatőr táncosok nagyobb mértékben elégedetlenek a testükkel, 96\%-uk a jelenleginél kisebb testsúlyt tart önmaga számára ideálisnak, míg profik esetében ez az érték csak 54,1\% (Diogo et al., 2016).

\section{VIZSGÁLAT}

\subsection{Résztvevők}

A vizsgálatban a Magyar Táncmúvészeti Egyetem hallgatói vettek részt, akik pszichológia kurzusok keretén belül töltötték ki a papír alapú kérdőívet vagy jutatták el azokat tánccal foglalkozó ismerőseiknek. Nagyrészt a mûvészképző végzős növendékei és a táncpedagógus képzésben részt vevő hallgatók vettek részt a kutatásban. A válaszadás önkéntes és anonim volt, a kérdőívet a pszichológia kurzusok végén volt lehetôségük kitölteni a hallgatóknak, ez körülbelül 20 percet vett igénybe.

A tavalyi évben összesen 151 fő hallgatta a pszichológia kurzusok valamelyikét. 108 fő vett részt a vizsgálatban, 2 főt kizártunk a terhessége miatt. A válaszadó táncosok 17-51 évesek voltak $(M=23,84, S D=5,98)$, a nemi megoszlás alapján $67 \%$ nő $(n=71)$ és $33 \%$ férfi $(n=35)$. Mivel az egyetemi kurzushoz kötődött a kitöltés, ezért nem meglepő, hogy 49,5\%-uk középfokú végzettségû (53 fő), míg 48,6\%-uk felsőfokú végzettséggel (52 fő) rendelkezik. A válaszadók 34,6\%-a profi táncos ( $\mathrm{n}=37$ fô), $43 \%$ nem hivatásos táncos $(\mathrm{n}=46$ fő $), 22,4 \%$ nem válaszolt $(\mathrm{n}=24$ fő) a kérdésre.

A részletesebb statisztikai elemzések érdekében további alcsoportokat képeztünk. Életkor alapján 3 csoportot különböztettünk meg: 1. csoport 17-19 évesek $(\mathrm{n}=19,17,9 \%)$; 2. csoport 20-29 évesek $(\mathrm{n}=77,72,6 \%) ; 3$. csoport 30 év felettiek $(\mathrm{n}=10$, 9,4\%.).

Az eredmények alapján a táncmúfajok tekintetében a résztvevők 32,7\%-a néptánc ( $\mathrm{n}=35$ fő), 2,8\%-a klasszikus balett ( $\mathrm{n}=3$ fő), 5,6\%-a modern tánc ( $\mathrm{n}=6$ fő), 11,2\%-a modern társastánc ( $\mathrm{n}=12$ fő) és $0,9 \%$ szinházi tánc $(\mathrm{n}=1$ fő) szakirány képviselője. A szakirányok összehasonlítását a néptánc, modern tánc és modern társastánc csoportok mentén végeztük, mivel a klasszikus balett és színházi tánc csoportokban túl 
alacsony volt a résztvevők száma. 50 fő nem adott választ a specializáció kérdésére. Ennek oka egyrészt az, hogy a kiadott kérdőívek egy részén nem szerepelt ez a kérdés, másrészt, amikor szerepelt, sem adtak rá választ egyesek, valószínúleg a beazonosíthatóságot akarták elkerülni. A következő vizsgálatban az online kitöltés ezen okok miatt is célravezetőbb.

\subsection{Vizsgálati eszköz}

Az önkitöltő kérdőív (3. táblázat) 7 nagyobb részből állt, és a következőket tartalmazta:

- demográfiai kérdések,

- antropometriai kérdések,

- általános egészségre vonatkozó kérdések:

- Egészségprofil Kérdőív (Health Survey, a továbbiakban és röviden: SF-36, Ware \& Sherbourne, 1992; magyarul: Czimbalmos et al., 1999)

- Goldberg-féle Általános Egészségi Kérdőív (General Health Questionnaire, a továbbiakban GHQ, Goldberg et al., 1978; magyarul: Karczag, 1988),

- WHO Általános Jóllét Skála (Bech et al., 1996, magyarra fordította és validálta: Susánszky et al. (2006))

- testi elégedettség:

- Testtel Kapcsolatos Elégedettség Skálája (Body Satisfaction Questionnaire, röviden és a továbbiakban BSQ, Folk, Pedersen \& Cullary, 1993, magyarra fordította: Szabó, 2003)

- Emberalakrajzok Tesztje (Human Figure Drawing Test, röviden és a továbbiakban: HFDT, Fallon \& Rozin, 1987, magyarra fordította: Szabó, 1991)

- testtel kapcsolatos attitúdök: Testtel Kapcsolatos Befektetések Skálája (Body Investment Scale, röviden és a továbbiakban BIS, Orbach \& Mikulincer, 1998, magyarra fordította: Lukács-Márton \& Szabó (2013),

- evéshez való viszonyulás: Evési Attitûdök Tesztje (Eating Attitudes Test, röviden, a továbbiakban EAT-12, Garner \& Garfinkel, 1979, magyarra fordította: Túry et al., 1990),

- önértékelés: Rosenberg Önértékelés Skála (Rosenberg Self-esteem Scale, röviden és a továbbiakban: R-SES, Rosenberg, 1965; magyarra fordította és validálta: Sallay et al., 2014). 
A táncos test

\begin{tabular}{|c|c|c|c|}
\hline Kérdőív részei & Alkalmazott teszt & Teszt alskálái & Kérdések száma \\
\hline $\begin{array}{l}\text { 1. Demográfiai } \\
\text { kérdések }\end{array}$ & & & 4 \\
\hline $\begin{array}{l}\text { 2. Antropometriai } \\
\text { kérdések }\end{array}$ & & & 10 \\
\hline \multirow{6}{*}{ 3. Általános Egészség } & $\begin{array}{l}\text { Egészségprofil Kérdőív } \\
\text { (SF-36) }\end{array}$ & & 1 \\
\hline & $\begin{array}{l}\text { WHO Általános Jóllét } \\
\text { Skála }\end{array}$ & & 5 \\
\hline & \multirow{4}{*}{$\begin{array}{l}\text { Általános Egészségi } \\
\text { Kérdőív (GHQ-28) }\end{array}$} & Szomatikus tünetek & 7 \\
\hline & & Szorongás és alvászavar & 7 \\
\hline & & Szociális diszfunkció & 7 \\
\hline & & Depresszió & 7 \\
\hline \multirow{2}{*}{ 4. Testi elégedettség } & $\begin{array}{l}\text { Testi Elégedettség } \\
\text { Kérdőíve (BSQ) }\end{array}$ & & 10 \\
\hline & $\begin{array}{l}\text { Emberalakrajzok } \\
\text { Tesztje (HFDT) }\end{array}$ & & 7 \\
\hline \multirow{4}{*}{$\begin{array}{l}\text { 5. Testtel kapcsolatos } \\
\text { attitúdök }\end{array}$} & \multirow{4}{*}{$\begin{array}{l}\text { Testtel Kapcsolatos } \\
\text { Befektetések Skálája } \\
\text { (BIS) }\end{array}$} & $\begin{array}{l}\text { Testtel kapcsolatos } \\
\text { érzelmi attitúdök skálája }\end{array}$ & 6 \\
\hline & & Testi kontaktus & 6 \\
\hline & & Testvédelem & 6 \\
\hline & & Testápolás & 6 \\
\hline \multirow{3}{*}{$\begin{array}{l}\text { 6. Evéshez való } \\
\text { viszonyulás }\end{array}$} & \multirow{3}{*}{$\begin{array}{l}\text { Evési Attitúdök Tesztje } \\
\text { (EAT-12) }\end{array}$} & Orális kontroll & 4 \\
\hline & & Diétázás & 4 \\
\hline & & Bulimia & 4 \\
\hline 7. Önértékelés & $\begin{array}{l}\text { Rosenberg-féle } \\
\text { Önértékelés Skála } \\
\text { (R-RES) }\end{array}$ & & 10 \\
\hline
\end{tabular}

3. táblázat: Az önkitöltô kérdőív részletezése

\subsection{Statisztikai elemzés}

A kapott eredményeket az SPSS 25.0 program segítségével elemeztük, kontrollcsoportos összehasonlítást nem alkalmaztunk. A kérdőíves vizsgálatból kapott adatokon normalitás vizsgálatot végeztünk, melynek eredménye a Shapiro-Wilk próba alapján 
az, hogy a változók túlnyomó többsége nem mutat normális eloszlást $(\mathrm{p}<0,005)$. A szerző́k ezért a továbbiakban nonparametrikus teszteket alkalmaztak.

A korrelációs vizsgálatoknál a Kendall-féle tau rangkorrelációs együtthatót számoltuk ki, két alcsoport összehasonlításánál a Mann-Whitney próbát, a több csoport összevetésénél pedig a Kruskal-Wallis próbát használtuk.

\section{EREDMÉNYEK}

\subsection{Antropometriai eredmények}

A megadott antropometriai értékek alapján kiszámoltuk a testtömegindex értékét, majd 3 kategóriába soroltuk a kapott eredményeket. A válaszadók nagy része, 80,4\% $(\mathrm{n}=86)$ normális testalkatú (BMI=18,5-24,9), túlsúlyos (BMI=25,0-29,9) 8,4\% ( $\mathrm{n}=9$ fö), és sovány testalkatú (BMI $<18,5)$ a táncosok 4,7\%-a (5 fő). 6 fô nem adott meg a BMI kiszámításához szükséges adatot (6,5\%). A túlsúlyos és sovány csoportok kis mérete miatt a BMI alapján létrehozott csoportokat nem tudjuk összehasonlítani.

Nemi bontásban vizsgálva a BMI-t, a nők 7,4\%-a ( $\mathrm{n}=5)$ sovány, $86,7 \%$-a $(\mathrm{n}=59)$ normális tápláltsági állapotú, 5,9\%-a $(\mathrm{n}=4)$ túlsúlyos. A férfiak csoportjában sovány táncost nem találtunk, a kitöltők 84,4\%-a ( $\mathrm{n}=27)$ normális tápláltsági állapotú, 15,6\%a $(\mathrm{n}=5)$ pedig túlsúlyos. Elhízott válaszadó egyik csoportban sem volt.

\section{2. Általános egészséggel kapcsolatos eredmények}

Az egészségi állapot felmérésénél a Goldberg-féle Általános Egészségi Kérdőívet (GHQ-28) és az Egészségprofil Kérdőívből származó tételt használtuk. A GHQ-28 esetében a szerzők a tünetekkel rendelkező csoport küszöbértékét 5/6 pontnál, a magas kockázatú, nagy valószínúséggel beteg csoport küszöbértékét 11 / 12 pontnál határozták meg (Goldberg \& Hillier, 1979; Goldberg \& Williams, 1988).

A GHQ-28 összpontszáma 20 fó esetében $(19,41 \%)$ nagy valószínúséggel megbetegedés jelenlétét mutatja, mely szomatikus és lelki jellegú is lehet. A nő́k 22,9\%-a $(\mathrm{n}=16)$ tünetekkel rendelkezik, 22,9\%-a $(\mathrm{n}=16)$ pedig valamilyen megbetegedésben szenved, 45,8\%-uk nem egészséges. A férfi táncosok 78,8\%-a egészséges, tünetei 9,1\%-uknak ( $\mathrm{n}=3)$ vannak, 12,1\%-uk ( $\mathrm{n}=4)$ valószínúleg betegséggel küzd. A GHQ28 belső megbízhatósága megfelelő az alskálák és az összpontszám Cronbach-alfa értékei alapján $(0,741-0,818)$.

\subsection{Testi elégedettséggel kapcsolatos eredmények}

A testi elégedettségre vonatkozóan a Testtel Kapcsolatos Elégedettség Skála (BSQ) ötfokozatú válaszlehetôséget kínál (1 - nagyon elégedetlen, 5 - nagyon elégedett). A test (átlag=3,26, $\mathrm{SD}=0,979$ ), a testsúly (átlag=3,02, $\mathrm{SD}=1,193$ ) és az edzettségi állapot (átlag=3,25, SD=1,153) megítélésének átlaga a legalacsonyabb a táncosok körében a többi testrészhez viszonyítva. Érdekes eredmény, hogy a táncos nők és férfiak testtel és testrészekkel kapcsolatos elégedettsége nem tér el egymástól, csupán egy testrészükkel elégedetlenebbek a nők, a lábaikkal $(\mathrm{U}=0,1529$ p=0,009). 


\section{A táncos test}

A testtel kapcsolatos elégedettség (Testtel Kapcsolatos Elégedettség Skála 2. tétele) szignifikáns mértékú negatív együttjárást mutat a GHQ-28 Szorongás és alvászavar alskálájával ( $\mathrm{r}=-0,268, \mathrm{p}=0,001)$, a GHQ-28 Szociális diszfunkciók alskálájával ( $\mathrm{r}=-0,226, \mathrm{p}=0,007)$, a GHQ-28 összpontszámával $(\mathrm{r}=-0,277, \mathrm{p}<0,001)$, az EAT Diétázás alkálájának pontszámával $(\mathrm{r}=-0,434, \mathrm{p}<0,001)$ és az EAT összpontszámával $(\mathrm{r}=-0,346, \mathrm{p}<0,001)$. Ez azt jelenti, hogy a táncosok minél elégedetlenebbek a testükkel, annál intenzívebben szoronganak, a társas területekről visszavonulnak és összességében véve kevésbé érzik magukat egészségesnek. Ugyanakkor a testtel kapcsolatos elégedettség pontszáma szignifikáns mértékú pozitív együttjárást mutat a BIS Testtel kapcsolatos érzelmek és attitüdök alskálájával ( $\mathrm{r}=0,607, \mathrm{p}<0,001)$ a BIS összpontszámával ( $\mathrm{r}=0,407, \mathrm{p}<0,001)$, a WHO Általános Jóllét Skála értékével $(\mathrm{r}=0,321, \mathrm{p}<0,001)$. A táncos csoportban tehát a magas testtel kapcsolatos elégedettség együtt jár a magasabb életminőséggel, az alacsony evészavaros pontszámokkal, ezen belül fôleg az alacsony diétázás pontszámokkal, a testtel kapcsolatos pozitív érzelmekkel és a testtel kapcsolatos befektetésekkel. Érdekes, hogy a testtel kapcsolatos elégedetlenség alapvetően nem a jelenlegi testsúllyal függ össze, hanem az ideálisnak vélt testméretektől való eltéréssel (testsúly, BMI).

A testkép értékelésében az Emberalakrajzok Tesztje volt a segítségünkre. A jelenlegi testalak megítélése szignifikáns mértékú negatív kapcsolatot mutat a BIS Testtel kapcsolatos érzelmek és attitúdök skálájával $(\mathrm{r}=-0,251, \mathrm{p}=0,001)$ és az EAT Orális kontroll értékeivel is $(\mathrm{r}=-0,237, \mathrm{p}=0,005)$. Ugyanakkor a jelenlegi testalak megítélésének értékei szignifikáns pozitív korrelációt mutatnak az EAT Diétázás pontszámával $(r=0,369, p<0,001)$. Ha a jelenlegi testalak nagyobb, akkor negatívabbak a testtel kapcsolatos érzelmek és attitúdök, alacsonyabb az orális kontroll, ugyanakkor magasabbak a diétázás pontszámok.

\subsection{Evészavarral kapcsolatos eredmények}

Az evészavar gyanúja az EAT összpontszáma alapján merülhet fel. Csak a nők csoportjában vannak olyan válaszadók, akiknél az EAT összpontszáma küszöbérték feletti (9 pont). A nők 11,6\%-nál ( $n=8)$ magas az evészavaros tünetek gyakorisága, míg a férfiak csoportjában nincs ilyen válaszadó.

Az EAT összpontszám több változóval is kapcsolatban van. Szignifikáns negatív kapcsolatot mutat a testi elégedettséggel $(\mathrm{r}=-0,346, \mathrm{p}<0,001)$, a testsúllyal kapcsolatos elégedettséggel $(\mathrm{r}=-0,354, \mathrm{p}<0,001)$, a jelenlegi és kívánatos testsúly közötti különbséggel ( $\mathrm{r}=-0,211, \mathrm{p}=0,009)$, a kívánatos BMI értékkel $(\mathrm{r}=-0,273, \mathrm{p}=0,001)$, a BIS Testtel kapcsolatos érzelmek és attitúdök skálájával ( $\mathrm{r}=-0,334, \mathrm{p}<0,000)$, a BIS összpontszámával $(\mathrm{r}=-0,204, \mathrm{p}=0,007)$ és a WHO Általános Jóllét Skála összpontszámával ( $\mathrm{r}=-0,198, \mathrm{p}=0,008)$. Minél gyakoribbak az evészavaros tünetek, annál alacsonyabb a testtel, testsúllyal kapcsolatos elégedettség, annál nagyobb a jelenlegi és kívánatos testsúly közti különbség, annál alacsonyabb a kívánatos BMI, annál gyérebb a testtel kapcsolatos érzelmek jelenléte, a testtel kapcsolatos befektetések mértéke, illetve annál rosszabb az életminőség.

A korrelációs vizsgálatok alapján ugyanakkor az EAT összpontszáma szignifikáns mértékû́ pozitív összefüggést mutat a GHQ Szorongás és alvászavar alskálájával ( $\mathrm{r}=0,202, \mathrm{p}=0,009)$, a jelenlegi és ideális testalak különbségének változójával 
$(\mathrm{r}=0,378, \mathrm{p}<0,001)$, és a jelenlegi és kívánatos BMI közötti különbséggel $(\mathrm{r}=0,311$, $\mathrm{p}<0,001)$. Az evészavarra utaló pontszámok együttjárnak a szorongásos tünetek megjelenésével, és az ideálisnak tartott testalaktól és BMI-tôl való jelentôs eltéréssel. Ez utóbbi mutatja a testtel kapcsolatos elégedetlenséget.

\section{5. Önértékeléssel kapcsolatos eredmények}

A táncos csoport önértékelésének pontszámait a Rosenberg-féle Önértékelés Kérdőív összpontszáma adta. Ez a változó szignifikáns mértékú pozitív kapcsolatot mutat a testtel és a testsúllyal kapcsolatos elégedettséggel $(r=0,149, p<0,001$, valamint $\mathrm{r}=0,261, \mathrm{p}<0,001)$, a kívánatos BMI-vel $(\mathrm{r}=0,255, \mathrm{p}<0,001)$, a BIS összpontszámával $(\mathrm{r}=0,431, \mathrm{p}<0,001)$, a BIS Testtel kapcsolatos érzelmek és attitúdök skálájával ( $\mathrm{r}=0,505$, $\mathrm{p}<0,001)$, a BIS Testi kontaktus alskálájával $(\mathrm{r}=0,193, \mathrm{p}=0,001)$, a BIS Testvédelem alskálájával $(\mathrm{r}=0,207, \mathrm{p}<0,001)$ és a WHO Általános Jóllét Skála összpontszámának változójával $(\mathrm{r}=0,359, \mathrm{p}<0,001)$. Ez azt jelenti, hogy a táncosok körében az önértékelés magasabb pontszámaival együtt jár a magasabb testtel és a testsúllyal kapcsolatos elégedettség, a magasabb kívánatos BMI, a test pozitívabb megítélése, továbbá az, hogy az egyén több érzelmet táplál a testével kapcsolatban, jobban preferálja a testi kontaktusokat, fokozottabban védi a testét, és magasabb az életminősége is.

Az önértékelés pontszám szignifikáns mértékben negatív kapcsolatot mutat az Egészségprofil Kérdôív tételével $(\mathrm{r}=-0,425, \mathrm{p}<0,001)$, a GHQ-28 összpontszámával $(\mathrm{r}=-0,307, \mathrm{p}<0,001)$ és összes alskálájával, az EAT összpontszámával $(\mathrm{r}=-0,246$, $\mathrm{p}=0,001)$, az EAT Diétázás alskálájával $(\mathrm{r}=-0,207, \mathrm{p}=0,007)$, és a jelenlegi és ideális testalak különbségének változójával $(\mathrm{r}=-0,176, \mathrm{p}=0,025)$. Minél magasabb tehát $\mathrm{az}$ önértékelés, testi-lelki értelemben annál egészségesebb a táncos, annál alacsonyabbak az evészavaros pontszámai, és annál kisebb a különbség a jelenlegi és az ideálisnak tartott testalakok között.

\subsection{Csoportbontások}

Egyik célkitúzésünk volt, hogy a táncosok csoportját nem homogén egészként kezeljük, hanem további alcsoportokra bontjuk. Nemek, korcsoportok és specializációk szerint alcsoportokat képeztünk, valamint a hivatásos és az amatôr táncosok összehasonlítását is elvégeztük. A khi-négyzet teszt alapján a hivatásos/amatőr csopor-

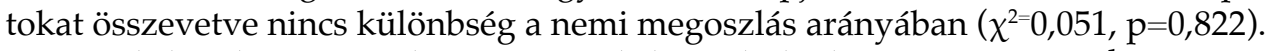

A nők körében a profik és amatőrök közti különbséget a Mann-Whitney próbával vizsgáltuk. Eltérés csupán a végzettség tekintetében mutatkozott (U=237,5, $\mathrm{p}=0,006$ ), a rangátlagokat figyelembe véve a profik iskolázottabbak.

Ugyanezt az összehasonlítást a férfiak csoportjában elvégezve már markánsabb különbségeket találtunk. A férfiak között a profik idősebbek $(U=23,5, p<0,001)$, az ideális női alakot vékonyabbnak tartják $(\mathrm{U}=36,5, \mathrm{p}=0,025)$ és a BIS Testápolás alskálán magasabb értéket érnek el $(\mathrm{U}=37,5, \mathrm{p}=0,023)$ (4. táblázat). A többi változó tekintetében nem található eltérés az amatôr és profi férfi táncosok között. 
A táncos test

\begin{tabular}{|l|c|c|c|c|}
\hline \multicolumn{1}{|c|}{ Változó } & $\begin{array}{c}\text { Profi } \\
\text { (n=12) } \\
\text { Átlag } \\
\text { (Rang átlag) }\end{array}$ & $\begin{array}{c}\text { Nem profi } \\
\text { (n=16) } \\
\text { Átlag } \\
\text { (Rang átlag) }\end{array}$ & $\begin{array}{c}\text { Mann-Whitney } \\
\text { U }\end{array}$ & p-érték \\
\hline kor & $\begin{array}{c}28,50 \\
(20,54)\end{array}$ & $\begin{array}{c}20,88 \\
(9,97)\end{array}$ & 23,5 & 0,001 \\
\hline ideális nói alak & $\begin{array}{c}3,54 \\
(9,32)\end{array}$ & $\begin{array}{c}4,32 \\
(15,89)\end{array}$ & 36,5 & 0,025 \\
\hline BIS: Testápolás alskála & $\begin{array}{c}22,00 \\
(17,75)\end{array}$ & $\begin{array}{c}20,31 \\
(10,84)\end{array}$ & 37,5 & 0,023 \\
\hline
\end{tabular}

4. táblázat: A profi és amatőr csoportok közötti különbségek férfi táncosoknál

\subsection{Korcsoportok}

Kor szerint az aktív táncos pályafutás szempontjából 3 részre osztották a szerzók a táncosokat: fiatalok (17-19 évesek), aktív táncosok (20-29 évesek) és idősebbek (30 éves kor felettiek). A csoportok kialakításakor a szerzők a táncos életpálya alakulását (Mihályi \& Szalay, 2015) és Erikson pszichoszociális fejlődéselméletét (Erikson, 2002) vették figyelembe.

A táncosok korcsoportonkénti összehasonlításakor a következő összefüggések adódtak. A jelenlegi testalak ( $\mathrm{H}=10,122, \mathrm{p}=0,006)$, a BIS Testvédelem $(\mathrm{H}=6,6622$, $\mathrm{p}=0,036)$, az EAT Bulimia alskála $(\mathrm{H}=7,768, \mathrm{p}=0,021)$ és az önértékelés összpontszámának $(\mathrm{H}=10,122$, p=0,006) szignifikáns eltérését kaptuk a Kruskal-Wallis próba alapján, melyet az 5. táblázat foglal össze részletesen. A jelenlegi testalak megítélésében a fiatalabbak választják a legvékonyabb testalakokat az Emberalakrajzok Tesztjében $(\mathrm{p}<0,005)$, szignifikáns mértékben eltérnek az aktív és az idősebb táncosoktól.

A további eltérések a legfiatalabb és az idősebb korcsoportok között jelentkeznek. A BIS Testvédelem alskálájának eltérése a két csoport között $(p=0,030)$ azt mutatja, hogy a fiatal táncosok kevésbé ügyelnek a testük védelmére. Ezt a korrelációs vizsgálatok is megerősítik az egész mintán. Az életkor szignifikáns pozitív kapcsolatot mutat a BIS Testvédelem alskálájával $(\mathrm{r}=0,212, \mathrm{p}=0,004)$. Tehát minél idősebb a táncos, annál jobban óvja a testét, több figyelmet szentel a test karbantartására

Az Evési Attitûdök Teszt Bulimia alskálájának eredményei ugyancsak a fiatalabb és az idősebb csoport között mutat szignifikáns különbséget $(p=0,020)$, a fiatalabb csoportban gyakoribbak a bulimiás tünetek.

Végül az önértékelés pontszámoknál megfigyelhető, hogy fiatalabb táncosok globális önértékelése az idősebb táncosokénál jóval alacsonyabb $(p=0,040)$. 
Szászi Beáta | Szabó Pál

\begin{tabular}{|l|c|c|c|c|c|}
\hline \multicolumn{1}{|c|}{ Változó } & $\begin{array}{c}\mathbf{2 0} \\
\mathbf{( n = 1 9 )}\end{array}$ & $\begin{array}{c}\text { Életkor (év) } \\
\mathbf{2 0 - 2 9} \\
(\mathbf{n = 7 7 )}\end{array}$ & $\begin{array}{c}\mathbf{7 2 9} \\
\mathbf{( n = 1 0 )}\end{array}$ & $\begin{array}{c}\text { Kruskal-Wallis } \\
\mathbf{( H )}\end{array}$ & p-érték \\
\hline $\begin{array}{l}\text { jelenlegi testalak } \\
\text { (Emberalakrajzok Tesztje) }\end{array}$ & $\begin{array}{c}2,88 \\
(33,78)\end{array}$ & $\begin{array}{c}3,64 \\
(52,51)\end{array}$ & $\begin{array}{c}4,66 \\
(67,67)\end{array}$ & 10,122 & 0,006 \\
\hline BIS Testvédelem & $\begin{array}{c}21,83 \\
(40,25)\end{array}$ & $\begin{array}{c}23,52 \\
(52,51)\end{array}$ & $\begin{array}{c}25,66 \\
(70,56)\end{array}$ & 6,622 & 0,036 \\
\hline EAT Bulimia & $\begin{array}{c}1,31 \\
(63,05)\end{array}$ & $\begin{array}{c}0,68 \\
(51,06)\end{array}$ & $\begin{array}{c}0,00 \\
(36,50)\end{array}$ & 7,768 & 0,021 \\
\hline önértékelés & $\begin{array}{c}28,22 \\
(38,72)\end{array}$ & $\begin{array}{c}30,70 \\
(49,96)\end{array}$ & $\begin{array}{c}34,44 \\
(67,44)\end{array}$ & 10,122 & 0,006 \\
\hline
\end{tabular}

5. táblázat: Korcsoportok összehasonlítása

\subsection{Specializációk eltérései}

A Kruskal-Wallis próba alapján szignifikáns különbségeket találtunk a modern társastánc, a néptánc és modern tánc csoportok között (6. táblázat). A testtel kapcsolatos elégedettség (Testtel Kapcsolatos Elégedettség Kérdőív 2. tétele) tekintetében szignifikáns eltérés van a 3 alcsoport között $(\mathrm{H}=8,939, \mathrm{p}=0,011)$. A társastáncosok mindkét csoporttól szignifikánsan különböznek ( $\mathrm{p}<0,005)$, náluk a legalacsonyabb a testtel kapcsolatos elégedettség. A testsúllyal kapcsolatos elégedettség (Testtel Kapcsolatos Elégedettség Kérdőív 9. tétele) is eltérést mutat $(\mathrm{H}=11,449, \mathrm{p}=0,003)$, a társastánc csoportban a legnagyobb az elégedetlenség mértéke $(\mathrm{p}<0,005)$.

A specializációk között az EAT összpontszáma is szignifikánsan különbözik $(\mathrm{H}=12,036, \mathrm{p}=0,002)$ : ebben az esetben is a társastáncos csoport mutatja a legkórosabb értéket $(\mathrm{p}<0,005)$. Az EAT Diétázás alskálán is $(\mathrm{H}=12,042, \mathrm{p}=0,002)$ a társastáncos csoport értéke a legmagasabb ( $\mathrm{p}<0,005)$. Az EAT Bulimia alskálán $(\mathrm{H}=6,374, \mathrm{p}=0,041)$ a társastáncos és néptáncos csoport között van szignifikáns különbség $(p=0,040)$. 
A táncos test

\begin{tabular}{|l|c|c|c|c|c|}
\hline \multicolumn{1}{|c|}{ Változó } & $\begin{array}{c}\text { Társastánc } \\
\mathbf{( n = 1 2 )} \\
\text { Átlag } \\
\text { (Rang átlag) }\end{array}$ & $\begin{array}{c}\text { Néptánc } \\
\text { (n=35) } \\
\begin{array}{c}\text { Átlag } \\
\text { (Rang átlag) }\end{array}\end{array}$ & $\begin{array}{c}\text { Modern tánc } \\
\mathbf{( n = 6 )} \\
\text { Átlag } \\
\text { (Rang átlag) }\end{array}$ & $\begin{array}{c}\text { Kruskal-Wallis } \\
\text { (H) }\end{array}$ & p-érték \\
\hline $\begin{array}{l}\text { Testtel kapcsolatos } \\
\text { elégedettség }\end{array}$ & $\begin{array}{c}2,75 \\
(16,33)\end{array}$ & $\begin{array}{c}3,63 \\
(29,40)\end{array}$ & $\begin{array}{c}4,00 \\
(34,33)\end{array}$ & 8,939 & 0,011 \\
\hline $\begin{array}{l}\text { Testsúllyal } \\
\text { kapcsolatos } \\
\text { elégedettség }\end{array}$ & $\begin{array}{c}2,25 \\
(14,92)\end{array}$ & $\begin{array}{c}3,40 \\
(29,40)\end{array}$ & $\begin{array}{c}4,00 \\
(37,17)\end{array}$ & 11,449 & 0,003 \\
\hline EAT összpontszám & $\begin{array}{c}6,00 \\
(37,75)\end{array}$ & $\begin{array}{c}2,56 \\
(24,88)\end{array}$ & $\begin{array}{c}0,5 \\
(13,17)\end{array}$ & 12,036 & 0,002 \\
\hline EAT Diétázás & $\begin{array}{c}3,83 \\
(38,08)\end{array}$ & $\begin{array}{c}1,29 \\
(16,42)\end{array}$ & $\begin{array}{c}0,16 \\
(24,19)\end{array}$ & 12,042 & 0,002 \\
\hline EAT Bulimia & 1,41 & $\begin{array}{c}0,20 \\
(24,24)\end{array}$ & $\begin{array}{c}0,33 \\
(0,33)\end{array}$ & 6,374 & 0,041 \\
\hline
\end{tabular}

6. táblázat: A táncmúfajok közötti különbségek összefoglalása

Érdekesség, hogy a specializációk nemenkénti bontását vizsgálva az EAT Diétázás alskáláján a társastán cosok értéke mindkét nemnél szignifikáns mértékben nagyobb, mint a néptáncos és modern táncos csoportoké. Anői táncosok 4 csoportját összevetve (néptánc, balett, társastánc, moderntánc)szignifikánseltérésekmutatkoznakatesttelés testsúllyal kapcsolatos elégedettség változóinál $(H=12,297, p=0,015$, illetve $H=15,128$, $\mathrm{p}=0,004)$, valamint az EAT Diétázás $(\mathrm{H}=11,721, \mathrm{p}=0,020)$, az EAT Bulimia $(\mathrm{H}=17,726$, $\mathrm{p}=0,001)$, és az EAT összpontszám $(\mathrm{H}=11,134, \mathrm{p}=0,025)$ változóinál. Minden esetben a társastáncos nők produkálják a magasabb, és ebben az esetben kórosabb értékeket.

\section{MEGBESZÉLÉS}

A táncosok a vizsgálat alapján rossz egészségi állapotban vannak, majdnem 20\%-uknál betegség valószínúsíthető, és ennél jóval több táncosnak szomatikus és/vagy pszichés tünete van. A nők majdnem fele $(45,8 \%)$ tünetekkel rendelkezik, vagy konkrét megbetegedéssel küzd. Ez a tény a sérülésveszélyek és az állóképesség szempontjából figyelemreméltó, és beavatkozást sürget. A kapott eredmények egyezést mutatnak egy nemzetközi vizsgálat magyar eredményeivel. Rathner és munkatársainak (1995) adatai szerint a magyar orvostanhallgatók csoportjában a nők 20,7\%-a vélhetően beteg, további 24,8\%-a tünetekkel rendelkezik (45,5\%). Férfiak esetében megbetegedéssel küzdhet a kitöltők 9,7\%-a, de tünetei további 22,2\%nak vannak.

Az eredmények szerint a táncosok 80,4\%-a $(\mathrm{n}=86)$ normális tápláltsági állapotú. A testtömegindex alapján a nők csoportjában van sovány válaszadó $(7,4 \%, \mathrm{n}=5)$, a férfiak között nincs. Múfajonként eltérô, de a táncos férfiaknak meghatározott izomtömegre van szükségük az emelésekhez, ugrásokhoz, ami magyarázza, hogy a táncos férfiak között nincsen sovány testtömegindexú válaszadó. Ezzel szemben a 
nőknek a színpadi megjelenésnél az esztétikus test kritériumai szerint produkálniuk kell a vékony alakot. A nők és a férfiak csoportjában is van túlsúlyos válaszadó: a nôknél 5,9\% (n=4fő), a férfiaknál 15,6\% (n=5fő). Elhízott személy az általunk vizsgált mintában nem volt.

A kapott eredmények jóval kedvezóbb értéket mutatnak, mint a hasonló kutatások. Burckhardt és munkatársainak (2011) táncos vizsgálati személyei csak 42,5\%ban rendelkeztek normális BMI-vel, 15,7\%-uk pedig súlyos mértékben sovány volt (Burckhardt et al., 2011). Az eredmények alapján a beavatkozásoknak nemcsak a súlyhiány, hanem az optimálistól eltérő, magasabb testsúly kezelésére is ki kell térniük.

A testtel kapcsolatos értékeléseket összegezve a táncos csoportban a testtel, a testsúllyal és az edzettségi állapottal kapcsolatos elégedettség a legalacsonyabb. Ez összhangban van Kazarez és munkatársai (2018), Robbeson és munkatársai (2013) és Özgen \& Kisac eredményeivel (2009), melyek szerint a profi képzésben részt vevố táncosok nagy arányban elégedetlenek a testükkel. A testtel kapcsolatos elégedettség ugyanakkor számos változóval áll kapcsolatban: a szociális aktivitással, a szorongás pontszámokkal, az egészségi állapottal és az életminőséggel is. Összességében a testtel való elégedettség elősegítése központi tényezőnek tûnik a táncos csoportban, ezért nagyon fontos, hogy a táncképzésben elősegítsük ennek kialakítását és fenntartását. Ezt az is alátámasztja, hogy a Testtel Kapcsolatos Befektetések Skálájának (BIS) összpontszáma és az alskálák értéke is szoros kapcsolatot mutat a testi elégedettséggel. Minél magasabb a testi elégedettség, annál pozitívabbak a testtel kapcsolatos attitû́dök, és a testvédelem is nagyobb mértékú.

Az evészavaros tünetek gyakoriságát tekintve a női táncosok $11,6 \%$-a $(\mathrm{n}=8)$ magas evészavar-kockázatot mutat, a férfiaknál nincsen küszöbérték feletti válaszadó. Az evészavarra vonatkozó adatok a hasonló kutatások eredményeinél alacsonyabbak, tehát az előfordulásuk jelen mintában kisebb. Az EAT nem diagnosztikai eszköz, konkrét evészavar meghatározására nem alkalmas, arra viszont igen, hogy az evészavaros tünetek jelenlétét mutassa. Az eredmények le Grange és munkatársai (1994) adataival mutatnak egyezést, akik felnőtt balerinák körében 4,1\%-nál anorexia nervosát, 8,2\%-nál pedig részleges anorexia nervosát állapítottak meg. Nascimento és munkatársai (2012) hasonló csoportban az anorexia nervosa gyakoriságát 15,8\%-nak találta, Liu és munkatársai (2016) serdülők körében a táncosok 15,4\%-nál talált evészavart. Több, célzottabb méróeszköz alkalmazásával, klinikai interjúval kiegészítve pontosabb képet kapnánk a mintában az evészavarok gyakoriságára vonatkozóan.

$\mathrm{Az}$ alcsoportok összehasonlításánál is érdekes eredményeket kaptunk az evészavarok tekintetében. A fiatalabb korosztályban gyakoribbak a bulimiás tünetek, a vizsgált táncmúfajok közül pedig a modern társastáncos csoportban magasabb az evészavaros tünetek gyakorisága (diétázás, bulimiás tünetek). Érdekesség, hogy ebben a csoportban az evészavaros tünetek mind a nők, mind a férfiak válaszainál is megjelennek. Diogo és munkatársai (2016) az evészavaros tüneteket gyakoribbnak találták a balett-táncos és jazztáncos lányoknál.

Az irodalmi áttekintésben idézett vizsgálatokkal ellentétben (Pierce et al., 1993; Radell, Adame \& Cole, 2020) a specializációk között több különbséget találtunk. Az EAT pontszámokon kívül a testtel és testsúllyal kapcsolatos elégedetlenség is 
magasabb a modern társastáncos csoportban, a néptáncos és modern táncos csoportokhoz viszonyítva. Figyelembe véve a színpadi megjelenést és a testalkati követelményeket, a baletthez képest a modern társastánc szabályai megengedóbbek. A színpadon elfogadott, esztétikus testalkat köre tágabb, azonban tény, hogy a modern társastánc esetében a versenypontszámok a ruházatra és a külső megjelenésre is kiterjednek. Ebből adódhat, hogy az evészavaros tünetek gyakoribbak ebben a csoportban.

Az önértékelés pontszámok a táncosok körében a testsúllyal kapcsolatos elégedettséggel és a BIS pontszámokkal állnak összefüggésben. Minél magasabb az önértékelés, annál intenzívebb a testvédelem és a testtel való foglalkozás, kevesebb a diétás megszorítás, és jobb az egészségi állapot. A fiatalabb táncosok (20 éves kor alattiak) önértékelése az idősebbekéhez (20 éves kor felettiek) képest nagyon alacsony, ehhez kapcsolódik az alacsony testvédelem, mindez pedig sérülékennyé teheti az aktív pálya előtt álló táncosokat. Érdekes jelenség, hogy a profi képzés végén a pályakezdő táncmúvészek (17-19 évesek) önértékelése alacsonyabb a szerzők által vizsgált két idősebb táncos korcsoporthoz képest (20-29 évesek, 30 éves kor felettiek). Monteiro és munkatársai (2014) vizsgálatukban BMI-kategóriánként vizsgálta a 9-15 éves diáklányok önértékelését. A tánccal foglalkozó lányok önértékelése magasabb, elégedettebbek a testsúlyukkal, a külsejükkel, mint a nem táncoló kortársaik. Ezzel szemben Robbeson és munkatársai (2013) arról számolnak be, hogy a női táncos válaszadók önértékelése alacsonyabb a nem táncos kontrollcsoporthoz viszonyítva. Ennek javítása érdekében a női táncosok továbbképzését szorgalmazza, melynek központi témája az egészséges testsúlykezelés elmélete és gyakorlata.

A kapott eredmények az intervenciós programok alkalmazását sürgetik, annak érdekében, hogy a profi képzésben a táncosok testtel kapcsolatos elégedettsége és az önértékelése magasabb legyen.

A hivatásos és amatőr táncosok nem különböztek egymástól az olyan releváns változók tekintetében, mint a testi elégedettség, evészavarok, testtel kapcsolatos befektetések, önértékelés, életminőség. A nők körében a profi és az amatôr válaszadók csupán a végzettség tekintetében tértek el, a férfi profi táncosok idősebbek, iskolázottabbak, többet foglalkoznak a testük ápolásával és szigorúbban ítélik meg az ideális nôi alakot. Diogo és munkatársai (2016) vizsgálatában az amatôr táncosok gyakrabban jeleztek evészavar tüneteket és nagyobb különbséget láttak a jelenlegi és az ideális testsúlyuk között, a profi táncosokhoz képest.

\section{KORLÁTOK}

Jelen vizsgálat legnagyobb korlátja, hogy csak korlátozott mértékben rendelkezik kontrollcsoportos összehasonlítással. A következő vizsgálatban a táncos csoport mellé korban, nemben és iskolai végzettség szintjében megegyező kontrollcsoportot illesztünk.

A kutatás korlátai nagyrészt az alkalmazott mérőeszközt érintik. A kiadott kérdőívek az általános kérdések tekintetében nem voltak teljesen egységesek, nem kérdeztünk rá minden kitöltőnél a specializációra. Érdekes tény, hogy a kérdésre adott rubrika gyakran üresen maradt abban az esetben is, amikor a kérdés szerepelt a 
kérdőívben. A következő vizsgálatban egységes, online kérdőívvel dolgozunk, ahol a specializáció jelölése kötelező lesz, ezzel azonosítható a táncmúfaj. A következő vizsgálatban ennek pótlása új elemzési szempontokat tesz lehetôvé: az 5 nagy specializációt külön bonthatjuk és összehasonlíthatjuk egymással.

A hivatásos és amatőr táncosok elkülönítése érdekében pontosan definiálni kell a kitöltốk számára a hivatásos táncos kifejezést, hogy jobban elkülöníthetőek legyenek a profi táncosok, a tanárok és a hallgatók.

$\mathrm{Az}$ antropometriai adatok megadásánál nem volt objektív mérőeszköz, ami alapján pontos testméretekkel tudtunk volna dolgozni, az adatok önbevalláson alapultak. A testméretekkel kapcsolatos adatok sokszor hiányosak voltak, ezért a következô, online vizsgálatban célszerû́ már a kérdőív elején figyelmeztetni a kitöltőket arra, hogy mérőszalagra és mérlegre lesz szükség.

Végül az evészavarok pontosabb meghatározásához több kérdőívet érdemes alkalmazni. Az EAT-12 tételes változata mellett alkalmazható az Evési Zavar Kérdôív (Eating Disorder Inventory, EDI; Garner, 1983; Túry et al., 1997), az evészavarok viselkedéses tüneteinek mérésére pedig az Evészavar Tünetek Súlyossági Skálája (Eating Behavior Disorder Severity Scale, EBSS; Yager, Landswerk \& Edelstein, 1987). Az evészavarok gyanúja a SCOFF kérdőívvel is kiszúrhető (Morgan, Reid \& Lacey, 1999; Dukay-Szabó, Simon, Varga, Szabó, Túry \& Rathner, 2016).

\section{KONKLÚZIÓ}

Az eredmények összegzése azt mutatja, hogy időszerú a komplex prevenciós program bevezetése a táncosok képzésében. A kutatásban részt vevő táncos kitöltók rossz egészségi állapotban vannak, testtel kapcsolatos elégedettségük pedig szoros kapcsolatban áll számos, hatékonyságukat meghatározó mutatóval (önértékelés, diétázás, szociális kapcsolatok, szorongás, egészségi állapot és életminőség). Különösen a korcsoportok összehasonlításánál érdemes kiemelni a fiatal korosztály sérülékenységét az alacsony önértékelés és az evészavaros tünetek tekintetében.

A táncmúfajok összehasonlítása alapján a rendelkezésre álló adatok azt mutatják, hogy a modern társastáncos csoport a leginkább veszélyeztetett az evészavarok szempontjából, a modern tánc képviselői pedig a legvédettebbek. A balett csoport vizsgálatára az alacsony elemszám miatt jelen vizsgálatban nem került sor. Az amatôr és profi táncosok közötti különbségek a legtöbb változó esetében elhanyagolhatók.

Ludányi \& Szabó (2017) a pedagógiai gyakorlatban megvalósítható evészavar-prevenciós módszerekről írtak részletes áttekintést. Az iskola színtere lehet az evészavaroknak és a testtel kapcsolatos elégedetlenségnek, ugyanakkor megelőző programoknak is helyet adhat, a diákok körében dolgozó valamennyi szereplő aktív részvételével. A táplálkozással kapcsolatos frontális előadásoktól napjainkban komplex programokig jutottunk, melyeknek része a médiatudatosság, viták, plakátok, paródiavideók készítése (Stice, Shaw \& Marti, 2007). Más programokban a drámajátékok kaptak helyet, a konfliktushelyzetek gyakorlása és a kommunikáció fejlesztése (Haines, Neumark-Sztainer, Perry, Hannan \& Levine, 2006). A programok fố célja, hogy azonosítsák a problémás egyéneket; információt nyújtsanak az evészavarok természetéről, és mindezek segítségével csökkentsék a jövőben kialakuló esetek számát. Általában nem az egyénekre, hanem közösségekre, baráti kapcsolatokra 


\section{A táncos test}

hatnak, és az emberek közötti viszonyulások változását indítják el, melynek eredményeképpen csökken a diákok közti kirekesztés, a karcsúságideállal való azonosulás, nő az önértékelés, a testtel kapcsolatos elégedettség, fejlődik az énkép és a testkép (Ludányi \& Szabó, 2017).

Táncosok körében több testtel kapcsolatos utánkövetéses intervenciós programot is sikerrel alkalmaztak, melyek a program végeztével is fenntartották hatásukat. Yannakoulia, Sitara és Matalas (2002) táncosok körében mérte a táplálkozással és evészavarokkal kapcsolatos prevenciós program hatékonyságát. Eredményeik szerint a résztvevők ismeretei fél évvel később is megmaradtak, mérhető volt a tanultak hatása a testösszetétel, a diétázás és a kóros evési szokások területén, sőt, további javulásokat is tapasztaltak.

Torres-McGehee és munkatársai (2011) evészavarokkal és táplálkozással kapcsolatos ismereteket tanítottak táncos fôiskolai hallgatóknak. Már 4 hét is elég volt ahhoz, hogy a táncosok soványság iránti vágya, depressziós pontszámai, testtel kapcsolatos félelmei és evészavaros tünetei csökkenjenek. Bettle és munkatársai (2001) időben hamarabb, korai serdülőkorban (11-12 éves kor) javasolják az intervenciós programok indítását. Javaslatuk szerint a testi elégedettséget az önértékelés javításával, serdülőkorban kell kialakítani, ezzel csökkenthető a pszichés megbetegedések kialakulásának valószínúsége. Jones és munkatársai (2014) még korábbi időszakban, kisiskolás korban javasolja a táplálkozással és az egészséges testkép formálásával kapcsolatos programokat, a rendezetlen evés serdülő táncos lányok körében ugyanis 14 éves kortól drasztikusan emelkedik. Ez előtt, még kisiskoláskorban (6-10 éves kor) célszerû́ felkészíteni a táncosokat a testtel kapcsolatos változásokra. Liu és munkatársai (2016) hasonlóan táncos serdülők vizsgálata alapján olyan prevenciós és képzési programokat javasol, amelyek segítségével a pozitív testkép kialakítása mellett érzelemszabályozási technikákra és a testtel kapcsolatos visszajelzések kezelését célzó stratégiákra is megtanítja a táncosokat.

Összegezve: a táncosokat fel kell készíteni a testüket érő fokozott fizikai és lelki terhelésre. Anatómiai, táplálkozástudományi, pszichológiai, biomechanikai ismeretekkel, a sérülések megelőzését célzó módszerekkel szükséges bővíteni a táncosok tudását annak érdekében, hogy felkészültebbek és ellenállóbbak legyenek. A Magyar Táncmúvészeti Egyetem kiemelten jó helyzetben van, mivel egy kampuszon múködik a középfokú és a felsőfokú intézmény, a bentlakásos kollégium és az Egészségfejlesztési Központ. Az egészségmegőrzésben és egészségfejlesztésben közös program keretében tudnak részt venni az egészségügyi, oktatási területek képviselői. Akár iskoláskortól formálható a gyermekek testtel kapcsolatos attitúdje, ezáltal kialakítható a pozitív testkép, a testtel kapcsolatos elégedettség és a magasabb önértékelés. Fontos, hogy ebbe a folyamatba minden résztvevő bevonható: a mesterek, a szülők, az osztályfőnök, a kollégiumi nevelőtanárok és az egészségügyi szakemberek (szakorvosok, dietetikus, pszichológus, gyógytornász). A prevenciós programoknak a tárgyi tudás átadása mellett a személyiségfejlesztô és konfliktuskezelési technikák gyakorlására kell koncentrálniuk. A frontális előadások helyett kiscsoportos és kooperatív technikák, drámapedagógiai eszközök, saját élményú önismereti feladatok használata javasolt. Ennek érdekében javasoljuk a kevert csoportok (akár múfajok között is) létrehozását. Fontos, hogy az intervenciós programok tartalmát minden résztvevő közvetítse a diákok 
számára, és hosszú távon a gyakorlatban is alkalmazza a táncoktatásban. A pozitív testkép kialakítása és fenntartása ugyanis folyamatos munkát és visszajelzést igényel, főként olyan tevékenységekkel alakítható ki, ahol az egyén kapcsolódni tud másokhoz, a tevékenység öröméért végzi a feladatot, és átérzi saját hatóerejét (Gattario \& Frisén, 2019).

\section{Irodalomjegyzék}

Ackard, D. M., Henderson, J. B., \& Wonderlich, A. L. (2004). The associations between childhood dance participation and adult disordered eating and related psychopathology. Journal of Psychosomatic Research, 57(5), 485-490. https:/ / doi. org/10.1016/j.jpsychores.2004.03.004

Allen, C. P., Telford R. M., Telford, R. D., \& Olive, L. S. (2019). Sport, physical activity and physical education experiences: associations with functional body image in children. Psychology of Sport and Exercise, 45(1-7). https: / doi.org/10.1016/j.psychsport.2019.101572

American Psychiatric Association (2013). Diagnostic and statistical manual of mental disorders (5 ${ }^{\text {th }}$ ed.). American Psychiatric Publishing. https: / doi.org/10.1176/appi. books.9780890425596

Arabia, J. J. M., Arabia, W. H. M., \& Hoyos, J. C. G. (2013). Lesiones en bailarines de ballet. Revista Cubana de Ortopedia y Traumatología, 27(1), 109-122.

Bech, P., Gudex, C., \& Johansen, K. S. (1996). The WHO (Ten) well-being index: validation in diabetes. Psychotherapy and Psychosomatics, 65, 183-190. https://doi. org / 10.1159/000289073

Bettle, N., Bettle, O., Neumärker, U., \& Neumärker, K. J. (2001). Body image and self-esteem in adolescent ballet dancers. Perceptual and Motor Skills, 93(1), 297309. https: / / doi.org/10.2466/ pms.2001.93.1.297

Burckhardt, P., Wynn, E., Krieg, M.-A., Bagutti, C., \& Faouzi, M. (2011). The effects of nutrition, puberty and dancing on bone density in adolescent ballet dancers. Journal of Dance Medicine E Science, 15(2), 51-60.

Burgess, G., Grogan, S., \& Burwitz, L. (2006). Effects of a 6-week aerobic dance intervention on body image and physical self-perceptions in adolescent girls. Body Image, 3(1), 57-66. https: / / doi.org/10.1016/j.bodyim.2005.10.005

Cash, T. F. (2002). Cognitive-behavioral perspectives on body image. In T. F. Cash, \& T. Pruzinsky (Eds.), Body Image. A handbook of theory, research and clinical practice. (pp. 478-486.) The Guilford Press.

Csenki L. (2015). Az énkép és a testkép szerepe a személyiség fejlődésében. In L. Révész, \& T. Csányi (Eds.), Tudományos alapok a testnevelés tanításához II. (pp. 49-70). Magyar Diáksport Szövetség.

Czimbalmos, Á., Nagy, Zs., Varga, Z., \& Husztik, P. (1999). Páciens megelégedettségi vizsgálat SF-36 kérdőívvel, a magyarországi normálértékek meghatározása. Népegészségügy, 80(1), 4-19. 
Diogo, M. A. K., de Oliveira Ribas, G. G., \& Skare, T. L. (2016). Frequency of pain and eating disorders among professional and amateur dancers. Sao Paulo Medical Journal, 134(6), 501-507. http: / / dx.doi.org/10.1590/1516-3180.2016.0077310516

Doyle-Lucas, A. F., Akers J. D., \& Davy, B. (2010). Energetic efficiency, menstrual irregularity, and bone mineral density in elite professional female ballet dancers. Journal of Dance Medicine E Science, 14(4), 146-154.

Dukay-Szabó, Sz., Simon, D., Varga, M., Szabó, P., Túry, F., \& Rathner, G. (2016). Egy rövid evészavar-kérdőív (SCOFF) magyar adaptációja. Ideggyógyászati Szemle, 69(3-4), https: / / doi.org/10.18071/isz.69.e014

Erikson, E. (2002). Gyermekkor és társadalom. Osiris Kiadó.

Fallon, A., \& Rozin, P. (1985). Sex differences in perception of desirable body shapes. Journal of Abnormal Psychology, 94, 102-105. https://doi.org/ 10.1037//0021843x.94.1.102

Folk, L., Pedersen, J., \& Cullari, S. (1993). Body satisfaction and self-concept of thirdand sixth-grade students. Perceptual and Motor Skills, 76(2), 547-553. https: / / doi. org / 10.2466/pms.1993.76.2.547

Garner, D. M., \& Garfinkel, P. E. (1979). The eating attitudes test: an index of the symptoms of anorexia nervosa. Psychological Medicine, 9(2), 273-279. https: / / doi. org / 10.1017/S0033291700030762

Garner, D. M., Olmstead, M. P., \& Polivy, J. (1983). Development and validation of a multi-dimensional eating disorder inventory for anorexia nervosa and bulimia. International Journal of Eating Disorders, 2, 15-34. https: / / doi.org/10.1002/1098-1 08X(198321)2:2<15::AID-EAT2260020203>3.0.CO;2-6

Gattario, K. H., \& Frisén, A. (2019). From negative to positive body image: men's and women's journeys from early adolescence to emerging adulthood. Body Image, 28, 53-65. https: / / doi.org/10.1016/j.bodyim.2018.12.002

Goldberg, D. P. (1978). Manual of the General Health Questionnaire (pp. 8-12). NFER-NELSON.

Goldberg, D. P., \& Hillier, V. F. (1979). A scaled version of the General Health Questionnaire. Psychological Medicine, 9(1), 139-145. https://doi.org/10.1017/ S0033291700021644

Goldberg, D. P., \& Williams, P. (1988). A user's guide to the General Health Questionnaire. NFER-Nelson.

Haines, J., Neumark-Sztainer, D., Perry, C. L., Hannan, P. J., \& Levine, M. P. (2006). V.I.K. (Very Important Kids). A school-based program designed to reduce teasing and unhealthy weight-control behaviors. Health Education Research, 21(6), 884895. https: / / doi.org/10.1093/her/ cyl123

Hausenblas, H. A., \& Fallon, E. A. (2006). Exercise and body image: a meta-analysis. Psychology and Health, 21, 33-47. https: / / doi.org/10.1080/14768320500105270

Hincapié, C. A., \& Cassidy, J. D. (2010). Disordered eating, menstrual disturbances, and low bone mineral density in dancers: a systematic review. Physical Medicine and Rehabilitation, 91(11), 1777-1789. https:/ / doi.org/10.1016/j.apmr.2010.07.230

Jones, L. E., Buckner, E., \& Miller, R. (2014). Chronological progression of body dissatisfaction and drive for thinness in females 12 to 17 years of age. Journal of Pediatric Nursing, 40(1), 21-25. 
Karczag, J. (1988) A Goldberg-féle Általános Egészség Kérdőív. In F. Mérei, \& F. Szakács (Eds.), Pszichodiagnosztikai vademecum I/2. (pp. 76-101). Tankönyv Kiadó.

Kazarez, M., Vaquero-Cristóbal, R., \& Esparza-Ros, F. (2018). Perception and distortion of body image in Spanish women dancers based on academic year and age. Nutrición Hospitalaria, 35(3), 661-668. http: / / dx.doi.org/10.20960 / nh.16

Kearney-Cooke, A. (2002). Familial influences on body image development. In T. F. Cash, \& T. Pruzinsky (Eds.), Body Image. A handbook of theory, research and clinical practice (pp. 99-107). Guilford Press.

Krasnow, D. M. S., \& Kabbani, M. (1999). Dance science research and the modern dancer. Medical Problems of Performing Artists, 14(1), 16-20.

Langdon, S. W., \& Petracca, P. (2010). Tiny dancer: body image and dancer identity in female modern dancers. Body Image, 7, 360-363. https: / / doi.org/10.1016/j.bodyim.2010.06.005

Lantos, K., Iván, E., Pászthy, B. (2008). A testkép és mérése. In F. Túry, \& B. Pászthy (Eds.), Evészavarok és testképzavarok (pp. 299-315). Pro Die Kiadó.

le Grange, D., Tibbs, J., \& Noakes, T. D. (1994). Implications of a diagnosis of anorexia nervosa in a ballet school. International Journal of Eating Disorders, 15(4), 369-376. https: / / doi.org/10.1002/ eat.2260150407

Liu, C.-Y., Tseng, M.-C. T., Chang, C.-H., Fang, D., \& Lee, M. B. (2016). Comorbid psychiatric diagnosis and psychological correlates of eating disorders in dance students. Journal of the Formosan Medical Association, 115(2), 113-120. https: / / doi. org/10.1016/j.jfma.2015.01.019

Ludányi, B., \& Szabó, P. (2017). Evészavarok és az iskola: kockázati tényező vagy a megelőzés terepe? Magyar Pedagógia, 117(1), 73-93. https:/ / doi.org/10.17670/ MPed.2017.1.73

Lukács-Márton, R., \& Szabó, P. (2015). Várandósság alatti evészavar: egy keresztmetszeti vizsgálat eredményei. In Zoltán Kondé (Ed.), Tanulmányok az Általános Pszichológiai Tanszék fennállásának 30. évfordulójára (pp. 194-208). Debreceni Egyetemi Kiadó.

McCrea, C. W., Summerfield, A. B., \& Rosen, B. (1982). Body image: a selective review of existing measurement techniques. British Journal of Medical Psychology, 55(3). https: / / doi.org/10.1111/j.2044-8341.1982.tb01502.x

Mihályi, G., \& Szalay, T. (2015). Nemzeti Táncprogram. Magyar Táncmúvészek Szövetsége. https://www.tancszovetseg.hu/images/documents / nemzeti_ tancprogram_2014_2015.pdf

Monteiro, L. A., Novaes, J. S., Santos, M. L., \& Fernandes, H. M. (2014). Body dissatisfaction and self-esteem in female students aged 9-15: the effects of age, family income, body mass index levels and dance practice. Journal of Human Kinetics, 43, 25-32. https: / / doi.org/10.2478/hukin-2014-0086

Morgan, J. F., Reid, F., Lacey, \& J. H. (1999). The SCOFF questionnaire: assessment of a new screening tool for eating disorders. British Medical Association, 319(7223), 1467-8. https: / / doi.org/10.1136/bmj.319.7223.1467

Nascimento, A. L., Luna, J. V., \& Fontenelle, L. F. (2012). Body dysmorphic disorder and eating disorders in elite professional female ballet dancers. Annals of Clinical Psychiatry, 24(3), 191-194. 
Nordin-Bates, S.M., Walker, I.J., Baker, J., Garner, J., Hardy, C., Irvine, S., Jola, C., Laws, H., \& Blevins, P. (2011). Injury, imagery, and self-esteem in dance healthy minds in injured bodies? Journal of Dance Medicine $\mathcal{E}$ Science, 15, 76-85. http:// www.ingentaconnect.com/ content/jmrp/jdms / 2011 / 00000015/00000002 / art00004

Orbach, I., \& Mikulincer, M. (1998). The Body Investment Scale: construction and validation of a body experience scale. Psychological Assessment, 10(4), 415-425. https: / / doi.org/10.1037/1040-3590.10.4.415

Özgen, L., \& Kisac, I. (2009). Drive for thinness, bulimia, and body dissatisfaction in Turkish ballet dancers and ballerinas. Procedia - Social and Behavioral Sciences, 1(1), 2218-2221. https: / / doi.org/10.1016/j.sbspro.2009.01.390

Pierce, E. F., Daleng, M. L., \& McGowan, R. W. (1993). Scores on exercise dependence among dancers. Perceptual Motor Skills, 76(2), 531-535. https: / / doi.org/10.2466/ pms.1998.86.3.771

Pierce, L. (2014). The integrative power of dance/movement therapy: implications for the treatment of dissociation and developmental trauma. The Arts in Psychotherapy, 41, 7-15. https: / / doi.org/10.1016/j.aip.2013.10.002

Polyák É. (2015). A tápláltsági állapot vizsgálata. In M. Figler (Ed.): Klinikai és gyakorlati dietetika (pp. 55-71). Medicina Könyvkiadó. https:/ / www.etk.pte.hu/public/upload/files/Palyazati_iroda/elnyert/Klinikai_es_gyakorlati_dietetika.pdf

Radell, S. A., Adame, D. D., \& Cole, S. P. (2002). Effect of teaching with mirrors on body image and locus of control in women college ballet dancers. Perceptual and Motor Skills, 95(3 Pt 2), 1239-1247. https: / / doi.org/10.2466/pms.2002.95.3f.1239

Rathner, G., Túry, F., Szabó, P., Geyer, M., Rumpold, G., \& Forgács, A. (1995). Prevalence of eating disorders and minor psychiatric morbidity in Central Europe before the political changes in 1989: A cross-cultural study. Psychological Medicine, 25(5), 1027-1035. https: / / doi.org/10.1017/S0033291700037521

Ravaldi, C., Vannacci, A., Zucchi, T., Mannucci, E., Cabras, P. L., Boldrini, M., \& Ricca, V. (2003). Eating disorders and body image disturbances among ballet dancers, gymnasium users and body builders. Psychopathology, 36, 247-254. https: / / doi.org/10.1159/000073450

Robbeson, J. G., Kruger, H. C., \& Wright, H. H. (2013). Disordered eating behavior, body image, and energy status of female student dancers. International Journal of Sport Nutrition and Exercise Metabolism, 25(4), 344-352. https: / / doi.org/10.1123/ ijsnem.2013-0161

Rosenberg, M. (1965). Society and the adolescent self-image. Princeton University Press. https: / / doi.org/10.1515/9781400876136

Rozin, P., \& Fallon, A. E. (1987). A perspective on disgust. Psychological Review, 94(1), 23-41. https: / / doi.org/10.1037/0033-295X.94.1.23

Sallay, V., Martos, T., Földvári, M., Szabó, T., \& Ittzés, A. (2014). A Rosenberg önértékelés skála (RSES-H): alternatív fordítás, strukturális invariancia és validitás. Mentálhigiéné és Pszichoszomatika, 15(3), 259-275. https: / / doi.org/10.1556/Mental.15.2014.3.7

Smolak, L. (2011). Body image development in childhood. In T. F. Cash, \& T. Pruzinsky (Eds.), Body Image. A handbook of science, practice and prevention (pp. 67-75). Guilford Press. 
Stice, E., Shaw, H., \& Marti, C. N. (2007). A meta-analytic review of eating disorder prevention programs. Encouraging findings. Annual Review of Clinical Psychology, 3, 207-231. https: / / doi.org/10.1146/ annurev.clinpsy.3.022806.091447

Susánszky, É., Konkolÿ-Thege, B., Stauder, A., \& Kopp, M. (2006). A WHO jól-lét kérdőív rövidített (WBI-5) magyar változatának validálása a Hungarostudy 2002 országos lakossági egészségfelmérés alapján. Mentálhigiéné és Pszichoszomatika, 7(3), 247-255. https:/ / doi.org/10.1556/Mental.7.2006.3.8

Swami, V., \& Tovée, M. J. (2009). A comparison of actual-ideal weight discrepancy, body appreciation, and media influence between street-dancers and non-dancers. Body Image, 6(4), 304-307. https:/ / doi.org/10.1016/j.bodyim.2009.07.006

Szabó, P. (2000). Testkép és testvázlat. In F. Túry, \& P. Szabó (Eds.), A táplálkozási magatartás zavarai: az anorexia nervosa és a bulimia nervosa (pp. 59-76). Medicina Könyvkiadó.

Thomas, J. J., Keel, P. K., \& Heatherton, T. F. (2011). Disordered eating and injuries among adolescent ballet dancers. Eating and Weight Disorders, 16(3), 216-222. https: / / doi.org/10.1007/BF03325136

Tosi, M., Maslyanskaya, S., Dodson, N. A., \& Coupey, S. M. (2019). The female athlete triad compares knowledge and risk in adolescent and young adult figure skaters, dancers, and runners. Journal of Pediatric and Adolescent Gynecology, 32(2), 165-169. https: / / doi.org/10.1016/j.jpag.2018.10.007

Treasure, J., Duarte, T. A., \& Schmidt, U. (2020). Eating disorders. Lancet, 395(10227), 899-911. https: / / doi.org/10.1016/S0140-6736(20)30059-3

Túry, F., Sáfrán, Zs., Wildmann, M., \& László, Zs. (1997). Az Evési Zavar Kérdőív (Eating Disorder Inventory) hazai adaptációja. Szenvedélybetegségek, 5, 336-342.

Túry, F., \& Pászthy, B. (2008). Evészavarok és testképzavarok. Pro Die Kiadó.

Túry, F., \& Szabó, P. (2000). A táplálkozási magatartás zavarai: az anorexia nervosa és a bulimia nervosa. Medicina Könyvkiadó.

Túry, F., Szabó, P., \& Szendrey, G. (1990). Evészavarok prevalenciája egyetemista populációban. Ideggyógyászati Szemle, 43, 409-418.

Vaquero-Cristobal, R., Alacid, F., Muyor, J. M., \& Lopez-Minarro, P. A. (2013). Body image; literature review. Nutrición Hospitalaria, 28, 27-35. https://doi. org /10.3305/nh.2013.28.1.6016.

Varnes, J. R., Stellefson, M. L., Janelle, C. M., Dorman, S. M., Dodd, V., \& Miller, M. D. (2014). A systematic review of studies comparing body image concerns among female college athletes and non-athletes, 1997-2012. Body Image, 10, 421-432. https:/ / doi.org/10.1016/j.bodyim.2013.06.001

Ventura, M. I., Barnes, D. E., Ross, J. M., Lanni, K. E., Sigvardt, K. E., \& Disbrow, E. A. (2016). A pilot study to evaluate multi-dimensional effects of dance for people with Parkinson's disease. Contemporary Clinical Trials, 51, 50-55. https://doi. org/10.1016/j.cct.2016.10.001

Ware, J. E., Jr., \& Sherbourne, C. D. (1992). The MOS 36-item short-form health survey (SF-36). I. Conceptual framework and item selection. Medical Care, 30(6), 473483. https: / / doi.org/10.1097/00005650-199206000-00002

Yager, J., Landsverk, J., \& Edelstein, C. K. (1987). A 20-month follow-up study of 628 women with eating disorders: I. course and severity. American Journal of Psychiatry, 144(9), 1172-1177. https: / / doi.org/10.1176/ ajp.144.9.1172 
A táncos test

Yannakoulia, M., Sitara, M., \& Matalas, A. L. (2002). Reported eating behavior and attitudes improvement after a nutrition intervention program in a group of young female dancers. International Journal of Sport Nutrition and Exercise Metabolism, 12(1), 24-32. https:/ / doi.org/10.1123/ijsnem.12.1.24

Zuława, G., \& Pilch, W. (2012). The estimation of nutrition habit of ballet school students in Krakow (Ocena sposobu żywienia uczennic Szkoły Baletowej Fundacji Artystycznej w Krakowie). Roczniki Panstwowego Zakladu Higieny, 63(1), 105-110. 